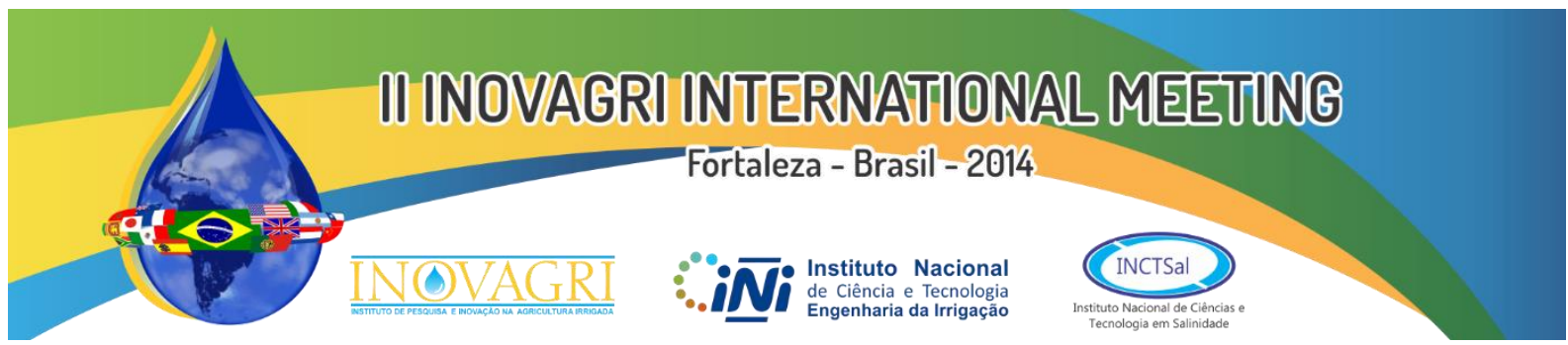

http://dx.doi.org/10.12702/ii.inovagri.2014-a109

\title{
SESAME CROP COEFFICIENTS, USING CROP EVAPOTRANSPIRATION BY WATER BALANCE AND, REFERENCE EVAPOTRANSPIRATION BY PENMAN-MONTEITH ${ }^{1}$
}

\author{
J. R. Pereira ${ }^{2}$, W. P. Araújo ${ }^{3}$, E. S. A. B. de Almeida ${ }^{4}$, J. R. C. Bezerra ${ }^{5}$, H. O. C. Guerra ${ }^{6}$, J. H. Zonta ${ }^{5}$
}

SUMMARY - To determine sesame BRS 196 CNPA G4 coefficients - Kc, at semiarid conditions, an experiment, irrigated with $100 \%$ of crop evapotranspiration - ETc, was installed at Embrapa Cotton, Barbalha, CE State, Brazil, in 2012. It was measured, with a Diviner $2000 \circledR$ probe, at each $10 \mathrm{~cm}$ soil depth, soil volumetric water content readings in three replications. The ETc $\left(\mathrm{mm} \mathrm{d}^{-1}\right)$ was calculated by the soil water balance equation $\left[E T c=I-R s \pm D / C \pm \Delta h\right.$, where $I=$ irrigation flows $\left(\mathrm{mm} \mathrm{d}^{-1}\right)$, Rs $=$ run-off flows $\left(\mathrm{mm} \mathrm{d}^{-1}\right), \mathrm{D} / \mathrm{C}=$ water drainage flows $\left(\mathrm{mm} \mathrm{d}^{-1}\right)$ and, $\Delta \mathrm{h}=$ soil water storage variation $\left.\left(\mathrm{mm} \mathrm{d}^{-1}\right)\right]$. It was determined soil water retention curves and parameters (by Richards Plates and by Genutchen method, respectively) and the saturated soil hydraulic conductivity (by infiltrometer method), too. To estimate the reference evapotranspiration - $\mathrm{ET}_{0}$, data required by Penman-Monteith equation were obtained from the weather station of the Instituto Nacional de Meteorologia, Barbalha, CE, Brazil. It was concluded that: 1) the sesame BRS 196 evapotranspiration - ETc was higher in the developmental/floration phase; 2) during its planting/establishment and maturation phases the sesame suffered water deficit, and; 3 ) the calculated sesame crop coefficients - Kc varied from 0.63 in the phase I (planting/establishment) to 0.97 in the phase III (developmental/floration) on its cycle.

KEYWORDS: Sesamum indicum L., water flows, water consumption.

\section{COEFICIENTES DE CULTIVO DO GERGELIM, UTILIZANDO EVAPOTRANSPIRAÇÃO DA CULTURA PELO BALANÇO HÍDRICO E, DE REFERÊNCIA POR PENMAN- MONTEITH}

RESUMO - Para determinar coeficientes de cultivo - Kc do gergelim BRS 196 CNPA G4, em condições semiáridas, experimento irrigado com $100 \%$ da evapotranspiração da cultura - ETc foi instalado na Embrapa Algodão, Barbalha, CE, em 2012. Mediu-se com uma Diviner 2000®, a cada $10 \mathrm{~cm}$, leituras de umidade em três repetições. A ETc $\left(\mathrm{mm} \mathrm{d}^{-1}\right)$ foi calculada pela equação do balanço hídrico [ETc $=\mathrm{I}-\mathrm{E}_{\mathrm{s}} \pm$ $\mathrm{Fv} \pm \Delta \mathrm{h}$, sendo $\mathrm{I}=$ irrigação $\left(\mathrm{mm} \mathrm{d}^{-1}\right), \mathrm{E}_{\mathrm{s}}=$ escoamento superficial $\left(\mathrm{mm} \mathrm{d}^{-1}\right), \mathrm{Fv}=$ fluxos descendentes/ascendentes de água $\left(\mathrm{mm} \mathrm{d}^{-1}\right) \mathrm{e}, \Delta \mathrm{h}=$ variação do armazenamento $\left(\mathrm{mm} \mathrm{d}^{-1}\right)$ ]. Determinou-se também curvas e parâmetros de retenção de água do solo (pelas Placas de Richards e pelo método de Genutchen, respectivamente) e a condutividade hidráulica do solo saturado (pelo método do infiltrômetro de anel). Para estimativa da evapotranspiração de referência, os dados da equação de Penman-Monteith foram obtidos da estação meteorológica do Instituto Nacional de Meteorologia, Barbalha, CE. Concluiu-se que: 1) a evapotranspiração do gergelim BRS 196 CNPA G4 - ETc foi maior na fase de desenvolvimento/floração; 2) nas fases de plantio/estabelecimento e de maturação o gergelim sofreu déficit

\footnotetext{
${ }^{1}$ Thesis extract of the first author on the Universidade Federal de Campina Grande - UFCG, Campina Grande, Paraíba State, Brazil

${ }^{2}$ Correspondent author; Agronomist, M. Sc., UFCG Doctor Degree Student. Embrapa Cotton Researcher. Rua Oswaldo Cruz, 1.143, Centenário, CEP 58.428-095, Campina Grande, PB State, Brazil. E-mail: jose.r.pereira@embrapa.br;

${ }^{3}$ Agronomist, M. Sc., UFCG Agricultural Engineering Department/Doctor Degree Student. Campina Grande, PB, Brazil. Email:wpacordao@hotmail.com;

${ }^{4}$ Agronomist. Embrapa Cotton General Cultures and Irrigation Department/Trainee. Campina Grande, PB, Brazil. E-mail: ericasamara@gmail.com;

5 Dr., Embrapa Cotton Researcher. Campina Grande, PB, Brazil. E-mail: jose.cortez-bezerra@embrapa.br; joaohenrique.zonta@embrapa.br;

6 Ph.D, UFCG Agricultural Engineering Department/Professor. Campina Grande, PB, Brazil. E-mail: hugo_carvallo@hotmail.com.
}

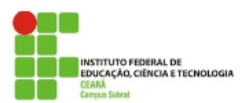


hídrico; e, 3) os coeficientes de cultivo - Kc do gergelim variaram de 0,63 na fase I (plantio/estabelecimento) a 0,97 na fase III (desenvolvimento /floração) do seu ciclo.

PALAVRAS-CHAVE: Sesamum indicum L., fluxos de água, consumo de água.

\section{INTRODUCTION}

The sesame crop, today little known in Brazil, may become an alternative for the grains production by the Brazilian Northeast and the Cerrados farmers, since as viewed as a functional food and to have good market prospects, especially its oil (GRILO JUNIOR \& AZEVEDO, 2013).

This crop presents good yield under semi-arid conditions of the Brazilian Northeast, but it is believed to obtain, under irrigation, a significant increase in yield, as attested by Milani et al. (2006) and Uçan et al. (2007). However, for the adoption of a sesame crop irrigated system urges the need to conduct research about your water consumption.

However, according to Souza et al. (2013), only the rainfall data are not sufficient to predict the amount of available water in the soil for crops since these inform as only the entry of water into the soil. It is necessary to know also the soil water balance.

To calculate the soil water balance for one culture is necessary to compute the entries of soil water via rainfall or irrigation, i. e. infiltration from the surface, and the outputs, represented by internal drainage, evapotranspiration and surface run-off in a soil volume based on the crop root system configuration, in a certain period of time (ALLEN et al., 2006; REICHARDT \& TIMM, 2012). The estimation of crop evapotranspiration - ETc, in turn, is based on the losses of water from the plant-soil system to the atmosphere through the processes of evaporation and transpiration (ALBUQUERQUE et al., 2002; ALLEN et al., 2006).

Information on sesame crop evapotranspiration - ETc and crop coefficients - Kc values that could subsidize irrigation management are scarce, as even the tabulated crop coefficients (Kc) values (initial Kc, middle Kc, end Kc), usually found in FAO reports (ALLEN et al., 2006), were obtained in regions outside Brazil, being more related, therefore, to a condition of sub-humid climate, not stressed cultures, reaching maximum production; however it is known that in actual field conditions, even in the same local and crop condition, these vary depending on local as well as the season conditions. For more arid conditions, such as the northeast semi-arid, with higher wind speeds, and many other factors outside of that standard condition, the use of those coefficients need corrections.

So, to ease the correction calculations, it is better to determine, in situ, the Kc, using methods that have been validated by research, such as the methods of the soil water balance to determine ETc and of Penman-Monteith for the estimation of $\mathrm{ET}_{0}$. The soil water balance method is characterized by to need a few parameters to its determination, and provides reliable values (FERNANDES et al., 1999). The Penman-Monteith method is the recommended by the FAO (ALLEN et al., 2006) to provide relatively accurate and consistent $\mathrm{ET}_{0}$ results in any geographic and climatic context.

Thus, this study aimed to: calculate the ETc through the soil water balance method; estimate the local $\mathrm{ET}_{0}$ by Penman-Monteith method, and so; calculate, in situ, the crop coefficients, quotients of the relationship between $\mathrm{ETc}_{\mathrm{c}}$ and $\mathrm{ET}_{0}$, in each phenological phase of the irrigated sesame BRS $196 \mathrm{CNPA}$ G4 crop cycle in the semiarid soil-climate conditions.

\section{MATERIALS AND METHODS}

The study was conducted at Embrapa Cotton Experimental Station, located in the Barbalha County, CE State, Brazil (Geographical coordinates: 07 $19^{\prime} \mathrm{S}, 39^{\circ} 18^{\prime} \mathrm{W}$ and $409 \mathrm{~m}$ above the mean sea level - RAMOS et al., 2009), in the Ceará South Mesoregion and the Ceará Cariri Microrregion, in the period from August $04^{\text {th }}$ to November $7^{\text {th }}, 2012$, in an area of Fluvic Neossoil, with surface layer predominantly clay-loamy, of medium fertility, but with low organic matter content, whose chemical characterization $(0-20 \mathrm{~cm})$, according to Bulletin $\mathrm{N}^{0} 33 / 2012$ of the Embrapa Cotton Soil Laboratory, Campina Grande, PB State, Brazil, was as follows: $\mathrm{pH}$ of 6.8, 95.3, 49.2, 2.8, 1.4 and $0.0 \mathrm{mmol}_{\mathrm{c}} \mathrm{dm}^{-3}$ of calcium, magnesium, sodium, potassium and aluminum, respectively, $5.4 \mathrm{mg} \mathrm{dm}^{-3}$ of phosphate and $12.3 \mathrm{~g} \mathrm{~kg}^{-1}$ of organic matter. Soil texture, in turn, at the surface layer $(0-30 \mathrm{~cm})$ was characterized as Clay Loam (33.67, 20.17 and $46.16 \%$ of sand, silt and clay, respectively) and at the $30-60 \mathrm{~cm}$ depth 
layer as Sand Clay-Loam (59.98, 15.10 and $24.92 \%$ of sand, silt and clay, respectively), as sample $\mathrm{N}^{\mathrm{o}}$ 33738 and $\mathrm{N}^{\circ} 33739$ of the UFCG Irrigation and Salinity Laboratory, Campina Grande, PB State, Brazil. The other soil physical characteristics of the experimental area (0-30 and 30-60 cm soil depth layers) are organized in Table 1.

The region climate is, according to Koppen's classification, "CSa" type, semi- humid, with hot and dry summer (4-5 months), with average maximum and minimum temperatures of $31.5{ }^{\circ} \mathrm{C}$ and of $20.5^{\circ} \mathrm{C}$, average relative humidity of $63 \%$ and average annual rainfall of $1,000 \mathrm{~mm}$, distributed in the months from March to June (RAMOS et al., 2009), whose obtained values at the place and time of the experiment are shown in Figure 1.

The water used for irrigation was of an artesian well, located near the experiment, classified as " $\mathrm{C}_{2} \mathrm{~S}_{1}$ " as Bulletin $\mathrm{N}^{\mathrm{o}}$ 42/2012 of the Embrapa Cotton Soil and Nutrition Laboratory, Campina Grande, PB, Brazil, presenting medium salinity and low concentration of sodium which may be used for irrigation whenever there is a moderate degree of leaching and special care in soil management.

The experimental area measured $6.912 \mathrm{~m}^{2}$ and was irrigated based in $100 \%$ crop evapotranspiration, which corresponds to an applied total net water depth of $567.50 \mathrm{~mm}$, with three replications. Soil preparation consisted of one plowing with chisel plowing. Foundation fertilization was taken at the bottom of the planting furrow as chemical soil analysis and recommendations for the culture in the region, i. e., $123-152-30 \mathrm{~kg} \mathrm{ha}^{-1}$. It was used in foundation (on August 05 ${ }^{\text {th }}$, 2012) 300 $\mathrm{kg} \mathrm{ha}^{-1}$ of Monoammonium Phosphate fertilizer - MAP $\left(11 \% \mathrm{~N}\right.$ and $\left.46 \% \mathrm{P}_{2} \mathrm{O}_{5}\right)$. Nitrogen was fractionated into two more times (44.5\% of the dose after thinning and $44.5 \%, 25$ days later, on September $05^{\text {th }}$ and $27^{\text {th }}, 2012$, respectively), each time applying $100 \mathrm{~kg} \mathrm{ha}^{-1}$ of Urea $\mathrm{N}$ fertilizer (45\% $\mathrm{N}$ ), while the $\mathrm{K}$ was all applied after thinning (on September $05^{\text {th }}, 2012$ ) at the rate of $50 \mathrm{~kg} \mathrm{ha}^{-1}$ of Potassium Chloride $\left(60 \% \quad \mathrm{~K}_{2} \mathrm{O}\right)$. Fertilization coverage was made in the lateral furrows of planting rows. Sowing was held on August $4^{\text {th }}, 2012$ with five seeds per hill and at an average depth of $2 \mathrm{~cm}$, using the BRS 196 CNPA G4 sesame cultivar (ARRIEL et al., 2010), 0.70 x 0.20 spaced, with final density of 8-10 plants per meter of row. The thinning was done in 2 steps: first, when plants had 4 leaves (pre-thinning) and the second when $15 \mathrm{~cm}$ tall (final thinning). The weed control was performed with 3 hand weedings.

Irrigations, in the total number of 22 in the cycle, were performed using conventional sprinkler system, considering a 75\% irrigation system efficiency, using sprinklers with $5.0 \times 4.6 \mathrm{~mm}$ nozzle, with a $0.34 \mathrm{MPa}$ service pressure, $18 \times 12 \mathrm{~m}$ spaced, with a $10.54 \mathrm{~mm} \mathrm{~h}^{-1}$ average precipitation, applying water until $0.40 \mathrm{~m}$, which according to Amaral \& Silva (2008), corresponds to the required soil profile effective depth by the root system of the sesame. Before planting, irrigations were performed in the entire area in order to bring the soil at field capacity and promote germination. Later, irrigations were performed every 3 and 4 days, due to clay-loamy soil textural characteristics of the area favoring slow water infiltration. From the beginning of the maturation stage (67 DAE) to the cycle finishing, irrigations became weekly.

The water application uniformity tests were performed on September $9^{\text {th }}, 2012$ (clean ground, before plants emergence) and on September $28^{\text {th }}, 2012$ (50 DAE - developmental/floration phase) in four replicates per date, using 9 rain gauges per test, equally spaced $(3 \mathrm{~m} \times 3 \mathrm{~m})$ within the area covered by 4 sprinklers, as Gomes (1994). With the collecting of the measured water volume of each rain gauge, obtained using a graduated recipient in millimeters, it was possible to determine the average precipitation sprinkler $\left(\mathrm{mm} \mathrm{h}^{-1}\right)$ by dividing the average collected volume $(\mathrm{mm})$ per gauge by the irrigation time (in hours). The average precipitation sprinkler considered in the irrigation calculations was derivated from all these tests and repetitions.

At each irrigation event, the water replacement $\left(\mathrm{ETc}=\mathrm{ET}_{0} * \mathrm{Kc}\right)$ was a function of $\mathrm{ET}_{0}$ estimated by the Penman-Monteith method, from respective period, using weather data from automatic weather station of the Instituto Nacional de Meteorologia - INMET, in Barbalha, CE State, Brazil, distant $500 \mathrm{~m}$ from experimental area and, of crop coefficients (Kc) given in FAO-56 (ALLEN et al., 2006). The $\mathrm{Kc}$ average for the different stages of growth, were as follows: Phase I planting/establishment - the period between emergence and 10\% ground cover (1-5 DAE): 0.63 . The values around average were obtained by the simplified equation by Albuquerque et al. (2002); Phase II - growth - period 10\% ground cover to the beginning of flowering (6-32 DAE): 0.79. The values around average were obtained by the equation $\mathrm{Kc}=0.0147+0.5125 *$ DAE; Phase III developmental/floration - the period between flowering and early maturation (33-66 DAE): 1.10; and, 
Phase IV - maturation - the period from early to late maturation (67-90 DAE): 0.25 . The values around average were obtained by the equation $\mathrm{Kc}=-0.0425+4.075 * \mathrm{DAE}$.

The period of study of the soil water balance was from August $10^{\text {th }}$ to November $7^{\text {th }}, 2012$, totaling 90 days and it was divided into 13 sub-periods, 1 with 9 days, 4 with 8 days, 5 with 7 days, 1 with 5 days and 2 with 4 days. The non-uniformity of the subperiods in number of days was due to soil volumetric water readings present some gaps.

The soil water balance was performed according to the methodology presented by Reichardt \& Timm (2012), Equation (1), for the 0 to $0.50 \mathrm{~m}$ soil depth, using data of daily readings $\left(\mathrm{mm} 10 \mathrm{~cm}^{-3}\right.$ of soil) at each $0.10 \mathrm{~m}$ soil depth (at $0.10,0.20,0.30,0.40,0.50$ and $0.60 \mathrm{~m}$ ) of access Diviner $2000 \circledR$ probe tubes (SENTEK, 2000), randomly installed in the plots. The Diviner $2000 \AA$ probe calibration equation is shown in Figure 2. Before the readings, the probe normalization it was done through readings in air and water.

$$
E T c=(P+I) \pm D / C \pm R s \pm \Delta S F \pm \Delta h \pm \Delta p
$$

where: ETc - crop evapotranspiration $(\mathrm{mm})$; P - rainfall $(\mathrm{mm})$, zero in driving time from work (RAMOS et al., 2009); I - irrigation (mm); D/C - deep drainage (-) or capillary rise (+) (mm) below the root zone contingency of crop; $\mathrm{R}_{\mathrm{s}}$ - run-off flows $(\mathrm{mm})$, null given the area is plan; $\Delta S F$ - subsurfaces flows $(\mathrm{mm})$ (minimum values usually being considered only on soils under conditions of high slope); $\Delta \mathrm{h}$ - soil water storage variation $(\mathrm{mm})$ in the operating area of the roots $(0-40 \mathrm{~cm}$ for Sesame) and, $\Delta \mathrm{p}$ - plant water content variation $(\mathrm{mm})$.

The deep drainage or capillary rise components $(\mathrm{D} / \mathrm{C})$ of soil water were calculated by the Darcy-Buckingham equation [Equation (2)], simplified by Reichardt \& Timm (2012):

$$
D / C=-\bar{K}(\theta) \frac{\Delta H_{t}}{\Delta z}
$$

where: $\bar{K}(\theta)$ is the unsaturated soil hydraulic conductivity $\left(\mathrm{mm} \mathrm{d}^{-1}\right)$, depending on soil volumetric water content; and, $\frac{\Delta H_{t}}{\Delta z}$, the soil water total potential gradient.

The soil water storage variation $(\mathrm{mm})$, determined by the difference of the soil volumetric water content values, obtained at the initial and the final time of each considered period, was measured at 0 to $0.40 \mathrm{~m}$ depth $(0.0 \mathrm{~cm}$ to $\mathrm{L})$, effective depth sesame roots, according to Equation (7), and the variation of the deep drainage and capillary rise flows $(\mathrm{D} / \mathrm{C}-\mathrm{mm})$ in the layer of 0.30 to $0.50 \mathrm{~m}$ according to equations (2) to (6). The average unsaturated soil hydraulic conductivity $\bar{K}(\theta)$, the soil water total potential variation $\left(\Delta H_{t}\right)$ and the soil water storage variation $(\Delta \mathrm{h})$ were obtained by numerical integrations using the trapezoidal graphical method (REICHARDT \& TIMM, 2012):

$$
\begin{aligned}
& \bar{K}(\theta)=K_{0} \frac{\left(\theta_{(L-z) f t}+\theta_{(L+z) f t}+\theta_{(L-z) i t}+\theta_{(L+z) i t}\right)}{4} \\
& \left|\Psi_{\mathrm{m}}\right|=\frac{\left\{\left[\left(\theta_{s}-\theta_{r}\right) /\left(\theta-\theta_{r}\right)\right]^{\wedge} 1 / m-1\right\}^{\wedge} 1 / n}{\alpha}
\end{aligned}
$$

$$
\begin{aligned}
H & =\Psi_{\mathrm{m}} \mid-z \\
\Delta H_{t} & =\frac{\left(H_{(L-z) i t}+H_{(L-z) f t}\right)}{2}-\frac{\left(H_{(L+z) i}+H_{(L+z) f t}\right)}{2}
\end{aligned}
$$




\section{$\Delta h=\left[\mu\left(\theta_{0} \ldots \theta_{L}\right)_{f t}\right]-\left[\mu\left(\theta_{0} \ldots \theta_{L}\right)_{i t}\right]^{*} \Delta Z$}

where: $\bar{K}(\theta)$ is the unsaturated soil hydraulic conductivity $\left(\mathrm{mm} \mathrm{d}^{-1}\right), \mathrm{K}_{0}$ is the saturated soil hydraulic conductivity $\left(\mathrm{mm} \mathrm{d}^{-1}\right), \mathrm{L}$ is the considered layer $(\mathrm{cm})$ for the soil water balance (effective depth crop roots), $\mathrm{z}$ (negative values) is the multiple of the depths $(\mathrm{cm})$ where the volumetric soil water content $\left(\mathrm{m}^{3} \mathrm{~m}^{-3}\right)$ are measured, $\boldsymbol{O}_{(L-z) f t}$ is the volumetric soil water content $\left(\mathrm{m}^{3} \mathrm{~m}^{-3}\right)$ at $\mathrm{L}-\mathrm{z}(\mathrm{cm})$ on final time, $\boldsymbol{\theta}_{(L+z) f t}$ is the volumetric soil water content $\left(\mathrm{m}^{3} \mathrm{~m}^{-3}\right)$ at $\mathrm{L}+\mathrm{z}(\mathrm{cm})$ on final time, $\theta(L-z)$ it is the volumetric soil water content $\left(\mathrm{m}^{3} \mathrm{~m}^{-3}\right)$ at $\mathrm{L}-\mathrm{z}(\mathrm{cm})$ on initial time, $\theta_{(L+z) i t}$ is the volumetric soil water content $\left(\mathrm{m}^{3} \mathrm{~m}^{-3}\right)$ at $\mathrm{L}+\mathrm{z}(\mathrm{cm})$ on initial time, $\Delta H_{t}$ is the soil water total potential variation at $\mathrm{L}-\mathrm{z}$ to $\mathrm{L}+\mathrm{z}(\mathrm{mm})$ soil depth, $H_{(L-z) \text { it }}$ is the soil water total potential $(\mathrm{mm})$ at $\mathrm{L}-\mathrm{z}(\mathrm{cm})$ soil depth on initial time, $\boldsymbol{H}_{(L-z) f t}$ is the soil water total potential (mm) at L - z (cm) soil depth on final time, $\boldsymbol{H}_{(L+z) \text { it }}$ is the soil water total potential $(\mathrm{mm})$ at $\mathrm{L}+\mathrm{z}$ (cm) soil depth on initial time, $H_{(L+z) f t}$ is the soil water total potential $(\mathrm{mm})$ at $\mathrm{L}+\mathrm{z}(\mathrm{cm})$ soil depth on final time, $\Delta z$ is the depth variation between $\mathrm{L}-\mathrm{z}$ and $\mathrm{L}+\mathrm{z}(\mathrm{cm})$ for the deep drainage and capillary rise flows, $\Delta Z$ is the depth variation between $0,0-\mathrm{L}(\mathrm{cm})$ for the soil water storage variation, $\mathcal{U}$ is the symbolic notation of the mean, $\left(\theta_{0} \ldots \theta_{L}\right)_{f t}$ are the volumetric soil water content $\left(\mathrm{m}^{3} \mathrm{~m}^{-3}\right)$ measured at each $\mathrm{z}$, from 0,0 to $\mathrm{L}$ soil depth $(\mathrm{cm})$ on final time, $\left(\theta_{0} \ldots \theta_{\mathrm{L}}\right)_{\text {it }}$ are the volumetric soil water content $\left(\mathrm{m}^{3} \mathrm{~m}^{-3}\right)$ measured at each $\mathrm{z}$, from 0,0 to $\mathrm{L}$ soil depth $(\mathrm{cm})$ on initial time, $\left|\Psi_{\mathrm{m}}\right|$ (absolute values) is the matricial potential (kPa), $\theta_{s}$ is the saturated volumetric soil water content $\left(\mathrm{m}^{3} \mathrm{~m}^{-3}\right)\left(\mathrm{m}^{3} \mathrm{~m}^{-3}\right), \theta_{r}$ is the residual volumetric soil water content $\left(\mathrm{m}^{3} \mathrm{~m}^{-3}\right)$ and, $\alpha, \mathrm{m}$ and $\mathrm{n}$ are water soil retention curve parameters (dimensionless) since $\theta<<1, \theta<\mathrm{m}<1$ and $\mathrm{n}>1$, according van Genutchen (1980) model.

The water soil retention curves, obtained from laboratory and field soil matricial potential $(\mathrm{kPa})$ and volumetric water content $\left(\mathrm{m}^{3} \mathrm{~m}^{-3}\right)$ data at 0-30 and 30-60 $\mathrm{cm}$ depths (Figure 3) were determined at the UFCG Irrigation and Salinity Laboratory, Campina Grande, PB, Brazil, using Richards plates. The water soil retention curves data were fitted by polynomial regression, as van Genuchten (1980) model, determined by SWRC software (Soil Water Retention Curve - Beta 3.0 version -. DOURADO NETO et al., 2000), with the obtained parameters and the soil saturated hydraulic conductivity $\left(\mathrm{K}_{0}\right)$ values, determined in the experimental area, by the method of infiltrometer method, organized in Table 2.

To estimate the saturated soil hydraulic conductivity $-K_{0}$ were held on October $17^{\text {th }} 2012$, three infiltration tests at different points of the experimental area with 25 and $50 \mathrm{~cm}$ diameter infiltrometers, both with $30 \mathrm{~cm}$ high, $15 \mathrm{~cm}$ buried in the ground surface as Bernardo et al. (2009). The Basic Infiltration Rate - BIR $\left(\mathrm{cm} \mathrm{h}^{-1}\right)$, i. e., the water infiltration rate into the soil at the time that it reaches the BIR, a more or less constant value of it which can be considered equal to the saturated soil hydraulic conductivity was obtained from Equation (8):

BIR time $(\min )=600 *$ ABS $(\mathrm{n})$

Since $\mathrm{n}$ is one of the constants of Potential Equation [equation (9)] that describes the soil water infiltration rate (IR), whose curve can be obtained by plotting the data of IR "versus" the accumulated time:

$$
\mathrm{IR}=\mathrm{R} \mathrm{T}^{\mathrm{n}}
$$


where IR $=$ is the soil water infiltration rate $\left(\mathrm{cm} \mathrm{h}^{-1}\right), \mathrm{R}=$ soil dependente constant (dimensionless), $\mathrm{T}=$ is the BSI time $(\mathrm{min})$ and, $\mathrm{n}=$ soil dependente constant that varies from 0 to 1 (dimensionless).

The reference evapotranspiration was determined in the 100\% crop evapotranspiration level by FAO-Penman-Monteith method, as equations (10) and (11) (ALLEN et al., 2006):

$$
\text { ETo }=\frac{0,408 \Delta(R n-G)+\gamma\left(\frac{900}{T+273}\right) U_{2}\left(e_{s}-e_{a}\right)}{\Delta+\gamma\left(1+0,34 U_{2}\right)}
$$

where: $\mathrm{ET}_{\mathrm{o}}$ is the reference evapotranspiration $\left(\mathrm{mm} \mathrm{d}^{-1}\right)$; $\mathrm{Rn}$ is the net radiation at crop surface (MJ m${ }^{-2}$ $\left.\mathrm{d}^{-1}\right)$; $\mathrm{G}$ is the soil heat flux density $\left(\mathrm{MJ} \mathrm{m}^{-2} \mathrm{~d}^{-1}\right)$, considered insignificant when using daily calculations; $\mathrm{T}$ is the air temperature at $2 \mathrm{~m}$ height $\left({ }^{\circ} \mathrm{C}\right) ; \mathrm{U}_{2}$ is the wind speed at $2 \mathrm{~m}$ heigh $\left(\mathrm{m} \mathrm{s}^{-1}\right) ; \mathrm{e}_{\mathrm{s}}$ is the saturation vapor pressure $(\mathrm{kPa}) ; \mathrm{e}_{\mathrm{a}}$ is the current vapor pressure $(\mathrm{kPa}) ; \Delta$ is the slope vapor pressure curve $\left(\mathrm{kPa}^{\circ} \mathrm{C}^{-1}\right) ; \gamma$ is the psychrometric constant $\left(\mathrm{kPa}^{\circ} \mathrm{C}^{-1}\right)$.

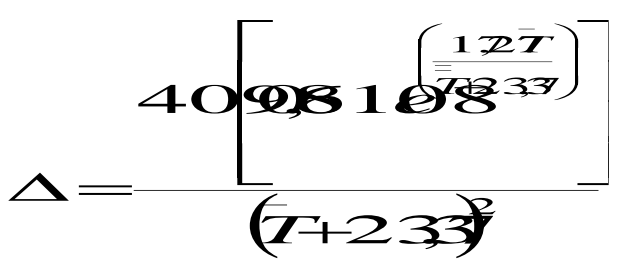

The psicrometric coefficient $(\gamma)$ é considerado constante, $\gamma=0,0622 \mathrm{kPa}{ }^{\circ} \mathrm{C}^{-1}$, is considered constant, $\gamma=0,0622 \mathrm{kPa}{ }^{\circ} \mathrm{C}^{-1}$, since it is a function of atmospheric pressure, which varies very little throughout the year $(95.03 \mathrm{kPa})$, and also of the water evaporation latent heat, that is little affected by temperature, being recommended an average value of $2.45 \mathrm{MJ} \mathrm{kg}^{-1}$.

The crop coefficients - Kc, were obtained for each sesame BRS 196 CNPA G4 phenological phase, by the relationship between the crop evapotranspiration (ETc) values, estimated by the soil water balance (REICHARDT \& TIMM, 2012), and the reference evapotranspiration (ET ${ }_{0}$ ) values, determined by the FAO-Penman-Monteith method [Equation (12)] (ALLEN et al., 2006), i. e.:

$$
K c=\frac{E T_{c}}{E T_{0}}
$$

\section{RESULTS AND DISCUSSION}

The water balance components in the soil cultivated with sesame BRS 196 CNPA G4 during the study period are presented in Table 3 and Figure 4 .

The sesame evapotranspiration (ETc) was the highest in the same subperiods (development/floration phase) on which major irrigation volumes occurred. This higher value of ETc under major irrigation volumes occur due to increased evaporation in the surface layers, as observations of Cruz et al. (2005). It is still observed in subperiods 11e 13 (maturation phase) that the ETc values are very low because few irrigations occurred on these subperiods. The highest ETc values on the growth and development/floration phases can be explained by the fact that, according to Weiss (1983), in sesame, the maximum water absorption occurs at flowering, gradually decreasing thereafter, leading thus to an increase in evapotranspiration at this phase. Moreover, on these phases and on maturation, greater irrigation volumes of irrigation occurred, which, as already mentioned, caused an increase in ETc. The ETc decreasing at end of cycle probably occurred, according to Lima et al. (2006) due to leaves senescence, reducing the leaf area and, thus the exposed area to transpiration (Table 3, Figure 4).

The average ETc results in the experiment ranged from 1.3 to $14.5 \mathrm{~mm} \mathrm{~d}^{-1}$, very different from those obtained by Chandrakar et al. (1994), in the Chhttisgarth region, India, in a sesame experiment under irrigation and by Amaral \& Silva (2008), with the own sesame BRS 196 CNPA G4, irrigated too, in Barbalha, CE, Brazil. 
The soil water storage variation $(\Delta \mathrm{h})$ showed positive values in subperiods $2,3,5,6,8,9$ and 12 with $3.7,0.5,14.2,14.6,9.2,15.0$ and $20.3 \mathrm{~mm} \mathrm{~d}^{-1}$, respectively. The subperiods $1,4,7,10,11$ and 13 showed negative values with $-3.7,-6.1,-11.7,-6.1,-14.6$ and $-10.9 \mathrm{~mm} \mathrm{~d}^{-1}$, respectively (Table 3 ).

The soil water drainage rates $(\mathrm{D} / \mathrm{C})$ values were positive in subperiods 1 to 6 - during planting/establishment and growth phases (totaling $4.5 \mathrm{~mm}$ ), i. e., capillary rise (C), and negative in subperiods 7 to 13 - development/floration and maturation phases (totaling $-2.5 \mathrm{~mm}$ ), indicating deep drainage (D). For the development/floration phase, where the largest amount of irrigation $(53.2 \mathrm{~mm})$ occurred, was provided higher deep drainage values, despite soil texture of the area having low infiltration capacity (Table 3, Figure 4), which disagrees with the results of Azevedo et al. (2006), where the increases of the irrigation water amounts resulted in similar increases of the soil water drainage rate. The low soil water drainage rate values found in this study may be due to the low hydraulic conductivity (Table 3) or, according to Fernandes et al. (1999) to`the normal difficulties encountered in the estimation of this term of the soil water balance equation.

It is also observed in Figure 4, that the period of highest sesame water requirement occurred in the development/floration phase, as agreed by Weiss (1983), with a total of $53.2 \mathrm{~mm}$, with the lower water requirement ocurring on planting/establishment phase with $29.6 \mathrm{~mm}$. The applied water total volume was $567.5 \mathrm{~mm}$. Interesting was the volume demanded by the growth phase to be smaller than the one of maturation phase, but Uçan et al. (2007) point out that the sesame is tolerant to lack of water in the soil during growth phase. This total irrigation amount is within of the suggested by Milani et al. (2006) who claim that sesame is very productive in regions with rainfall between $400-650 \mathrm{~mm}$.

Regarding to the $\mathrm{ET}_{0}$ values, they were superior to ETc during planting/establishment and maturation phases, but being much larger in this second phase, indicating that on these phases sesame suffered water deficit, also evidenced by the negative soil water storage values (Figure 4, Table 3).

Finally, from the relationship between the ETc values, calculated by the soil water balance, and the $\mathrm{ET}_{0}$ values, estimated by the Penman-Monteith method, were obtained, in situ, for each sesame BRS 196 CNPA G4 phenological phase, the respective crop coefficients - Kc which are distributed in Table 4.

Notably, the sesame BRS 196 CNPA G4 Kc value for phase III (development/floration phase) (Table 4) obtained in this study, approaches for less to the reported by Allen et al. (2006) and, for more, to the found by Amaral \& Silva (2008). The Kc value of the phase IV (maturation phase) (Table 4), in turn, was nearly twice that found by Allen et al. (2006). According Albuquerque et al. (2002) and Allen et al. (2006), even for the same crop, the Kc value is not constant, it changes depending on climatic as well as season conditions and crop characteristics throughout its cycle.

\section{CONCLUSIONS}

1. The sesame BRS 196 CNPA G4 evapotranspiration was higher in the development/floration phase, and smaller during planting/establishment and maturation ones;

2. During planting/establishment and maturation phases, the sesame BRS 196 CNPA G4 suffered water deficit, denoted by the much larger values of reference evapotranspiration in relation to the crop evapotranspiration and by the negative values of soil water storage, and;

3. The sesame BRS 196 CNPA G4 coefficients values varied from 0.63 in phase I (planting/establishment) to 0.97 in phase III (development/floration) of its cycle.

\section{BIBLIOGRAPHICAL REFERENCES}

ALBUQUERQUE, P. E. P de; ANDRADE JUNIOR, A. S. de; SOUZA, F. de; SEDIYAMA, G. C.; BEZERRA, J. R. C.; STONE, L. F.; SILVEIRA, P. M. da. Coeficientes de cultivos das principais culturas anuais. Item, n.52/53, p.49-57, 2002.

ALLEN, R. G.; PEREIRA, L. S.; RAES, D.; SMITH, M. Evapotranspiración del cultivo: Guias para la determinación de los requerimentos de agua em los cultivos. Rome: FAO, 2006. 298p. (Estudio FAO. Riego y Drenaje, 56).

AMARAL, J. A B. do; SILVA, M. T. Evapotranspiração e coeficiente de cultivo do gergelim por manejo de irrigação. Revista Brasileira de Oleaginosas e Fibrosas, v.12, n.1, p.25-33, 2008. 
ARRIEL, N. H. C.; ANDRADE, F. P. de; VIEIRA, D. J.; FIRMINO, P. T.; BELTRÃO, N. E. de M.; FREIRE, E. C.; BOUTY, F. de A. C.; COUTINHO, J. L. B.; VASCONCELOS, O. L; PINTO, J. M.; ROCHA, E. M. de M.; AMIM, S. M. F.; OLIVEIRA, J. S. de; AMABILE, R. F.; ASSIS, R. L. de; GUEDES, A. R.; ALENCAR, A. R. de; BIDÔ, L.; COSTA, I. T. da; DANTAS, E. S. B.; PEREIRA, J. R. Cultivar BRS 196 CNPA G4 e seu sistema de cultivo. Campina Grande: Embrapa Algodão, 2010 (Folder). n. p.

AZEVEDO, P. V. de; INAJÁ, I. F. de; SILVA, B. B. da; SILVA, V. de P. R. da. Water-use efficiency of dwarf-green coconut (Cocos nucifera L.) orchards in northeast Brazil. Agricultural Water Management, v.84, p.259-264, 2006. http://dx.doi.org/10.1016/j.agwat.2006.03.001

BERNARDO, S.; SOARES, A. A.; MANTOVANI, E. C. Manual de irrigação. 8 ed.Viçosa: UFV, 2009. 625p.

CHANDRAKAR, B. L.; SEKHAR, N; TUTEJA, S. S.; TRIPATHI, R. S. Effect of irrigation and nitrogen on growth and yield of summer sesame (Sesamum indicum). Indian Journal of Agronomy, v.39, n.4, p.701-702, 1994.

CRUZ, A. C. R.; LIBARDI, P. L.; CARVALHO, L. A.; ROCHA, G. C. Balanço de água no volume de solo explorado pelo sistema radicular de uma planta de citros. Revista Brasileira de Ciência do Solo, v.29, p.1-10, 2005. http://dx.doi.org/10.1590/S0100-06832005000100001

DOURADO NETO, D.; NIELSEN, D. R.; HOPMANS, J. W.; REICHARDT, K.; BACCHI, O. O. S. Software to model soil water retention curves (SWRC, version 2.00). Scientia Agrícola, v.57, n.1, p.191-192, 2000. http://dx.doi.org/10.1590/S0103-90162000000100031

FERNANDES, E. J.; TURCO, J. E. P.; RODRIGUES, T. de J. D. Balanço hídrico do solo em cultura de soja irrigada. Engenharia Agrícola, v.19, n.1, n.p., 1999.

GOMES, H. P. Engenharia de irrigação: Hidráulica dos sistemas pressurizados, aspersão e gotejamento. João Pessoa: Universitária/UFPB, 1994. 344p.

GRILO, J. A. S.; AZEVEDO, P. V. Crescimento, desenvolvimento e produtividade do gergelim BRS Seda na agrovila de canudos, em Ceará Mirim (RN). Holos, v.29, n.2, p.19-33, 2013.

LIMA, J. R. S.; ANTONINO, A. C. D.; SOARES, W. A.; SOUZA, E. S.; LIRA, C. A. B. O. Balanço hídrico no solo cultivado com feijão caupi. Revista Brasileira de Ciências Agrárias, v.1, p.89-95, 2006.

MILANI, M.; COUTINHO, D.; BALLARIS, A. L. Avaliação de genótipos de Gergelim (Sesamum indicum L.) em Ribeirão Preto/SP. Campina Grande: Embrapa Algodão, 2006. 19p. (Boletim de Pesquisa e Desenvolvimento, 66).

RAMOS, A. M.; SANTOS, L. A. R. dos; FORTES, L. T. G (Orgs.) Normais climatológicas do Brasil: 1961-1990. Brasília: INMET, 2009. 465p.

REICHARDT, K.; TIMM, L. C. Solo, planta e atmosfera: conceitos, processos e aplicações - Balanço hídrico. 2.ed. Barueri: Manole, cap.15, 2012. p.317-336.

SENTEK. Diviner 2000: user guide version 1.21. Sidney: Sentek Pty Ltd., 2000.

SOUZA, C. de; ANDRADE, A. P. de; LIMA, J. R. de S.; ANTONINO, A. C. D.; SOUZA, E. S. de; SILVA, I. de F. da. Balanço hídrico da cultura da mamona sob condições de sequeiro. Revista Brasileira de Engenharia Agrícola e Ambiental, v.17, n.1, p.3-10, 2013. http://dx.doi.org/10.1590/S1415-43662013000100001

UÇAN, K.; KILLI, F.; GENÇOGLAN, C.; MERDUN, H. Effect of irrigation frequency and amount on water use efficiency and yield of sesame (Sesamum indicum L.) under field conditions. Field Crops Research, v.101, p.249-258, 2007. http://dx.doi.org/10.1016/j.fcr.2006.11.011

VAN GENUCHTEN, M. T. A closed-form equation for predicting the hydraulic conductivity of unsaturated soils. Soil Science Society of America Journal, v.44, n.1, p.898-982, 1980.

WEISS, E. A. Sesame. In: WEISS, E. A. Oilseed crops. London: Longman, 1983. p.282-340. 


\section{J. R. Pereira et al.}

Table 1. Soil physical characteristics in the experimental area. Barbalha. CE. Brazil. 2012.

\begin{tabular}{lrr}
\hline Caracteristics & $0 \mathrm{a} 30 \mathrm{~cm}$ & $30 \mathrm{a} 60 \mathrm{~cm}$ \\
\hline Bulk density $\left(\mathrm{g} . \mathrm{cm}^{-3}\right)$ & 1.74 & 1.44 \\
Global density $\left(\mathrm{g} . \mathrm{cm}^{-3}\right)$ & 2.72 & 2.72 \\
Porosity (\%) & 35.82 & 47.04 \\
Natural water content (\%) & 0.86 & 0.65 \\
Water content in 0.10 atm (\%) & 45.90 & 32.10 \\
Water content in 0.33 atm (\%) & 35.10 & 25.10 \\
Water content in 1.00 atm (\%) & 28.72 & 17.76 \\
Water content in 5.00 atm (\%) & 22.73 & 12.55 \\
Water content in 10.0 atm (\%) & 20.27 & 11.61 \\
Water content in 15.0 atm (\%) & 18.55 & 9.98 \\
Available water content (\%) & 16.55 & 15.12 \\
\hline
\end{tabular}

Samples No 33738 and 33739 respectively of the UFCG Irrigation and Salinity Laboratory. Campina Grande. PB. Brazil.

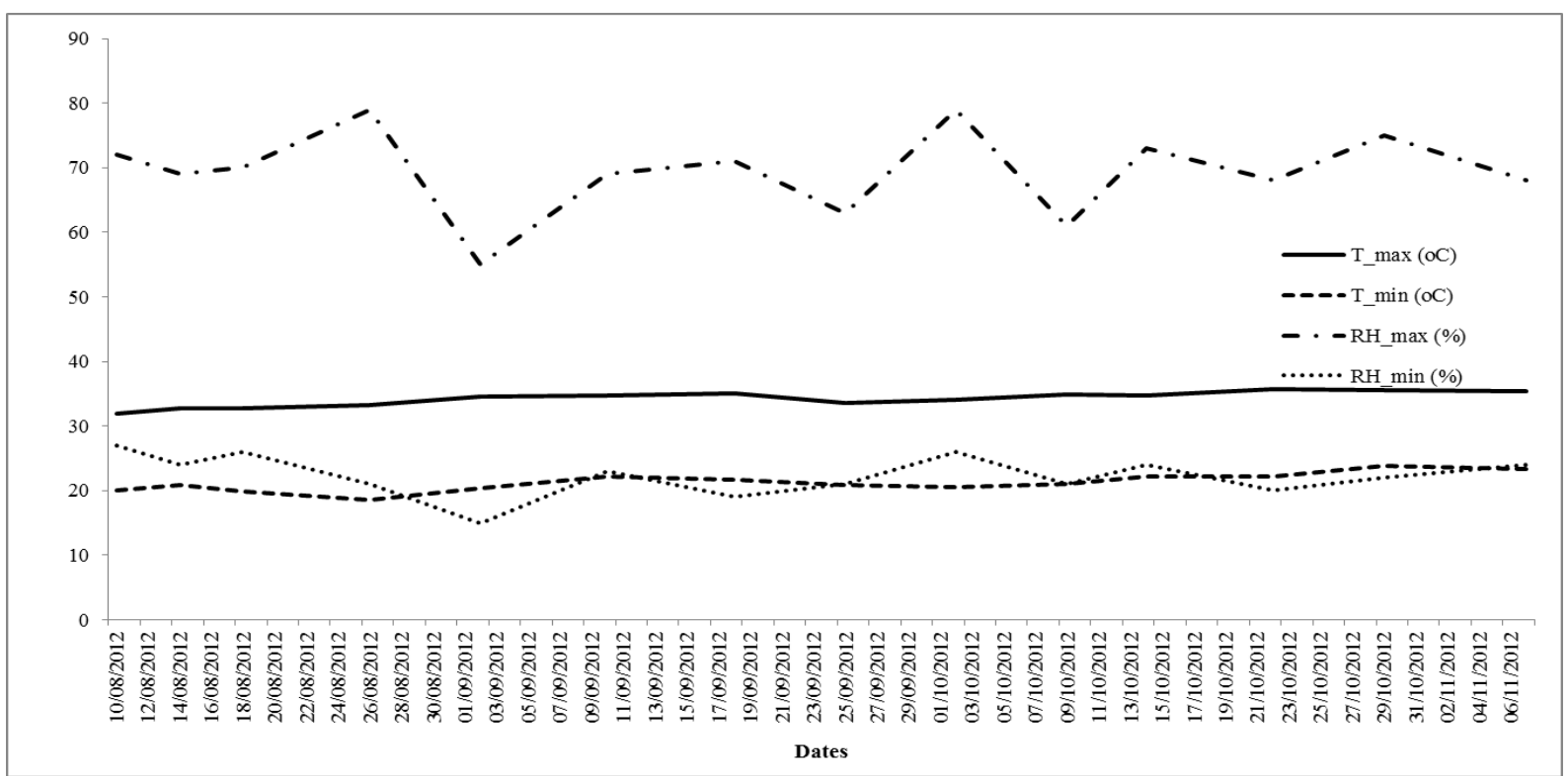

Figure 1. Average values of maximum (T_max) and minimum (T_min) temperatures and of maximum (RH_max) and minimum (RH_min) air relative humidity. obtained at the place and time of the experiment. Barbalha. CE. Brazil. 2012.

Table 2. Soil water retention curves parameters and soil saturated hydraulic conductivity $\left(\mathrm{K}_{0}-\mathrm{mm} \mathrm{d}^{-1}\right)$ determined at 10 to 50 cm depths. Barbalha. CE. Brazil. 2012.

\begin{tabular}{cccccc}
\hline Parameters & \multicolumn{4}{c}{ Depths $(\mathrm{cm})$} & \\
\cline { 2 - 5 } & 10 & 20 & 30 & 40 & 50 \\
\hline $\mathrm{A}$ & 1.4690 & 1.4690 & 1.4690 & 0.0693 & 0.0693 \\
$\mathrm{M}$ & 0.0947 & 0.0947 & 0.0947 & 0.0728 & 0.0728 \\
$\mathrm{~N}$ & 2.9170 & 2.9170 & 2.9170 & 5.3548 & 5.3548 \\
$\Theta \mathrm{r}$ & 0.0950 & 0.0950 & 0.0950 & 0.0560 & 0.0560 \\
$\Theta \mathrm{s}$ & 0.8600 & 0.8600 & 0.8600 & 0.3240 & 0.3240 \\
\hline $\mathrm{K}_{0}$ & 19.070 & 19.070 & 19.070 & 19.070 & 19.070 \\
\hline
\end{tabular}




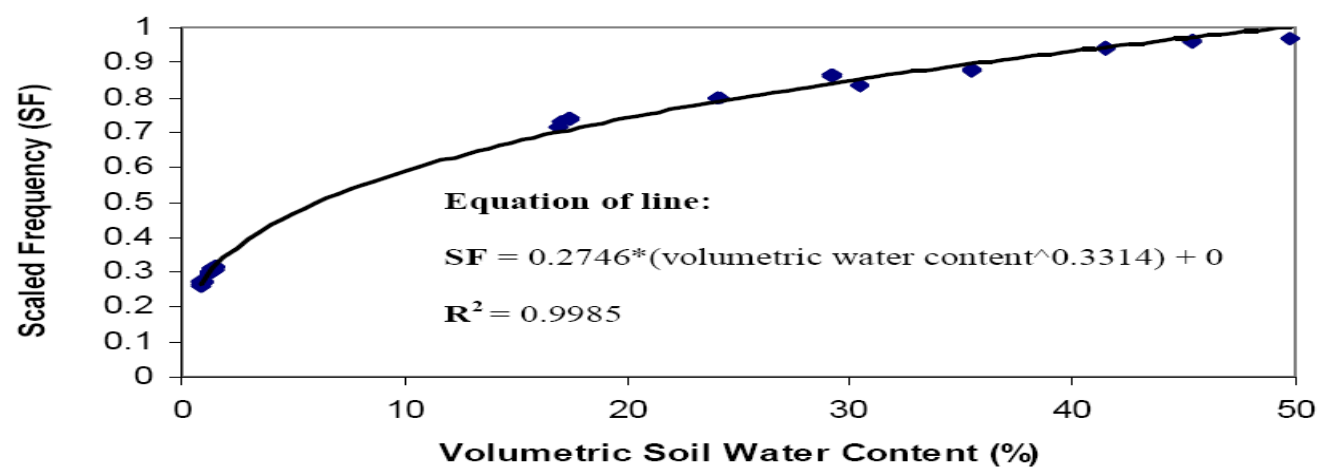

Figure 2. Diviner 2000® probe calibration equation (SENTEK. 2000).

Table 3. Water balance components in soil cultivated with sesame BRS 196 CNPA G4 during the period from August $10^{\text {th }}$ to November $7^{\text {th }} .2012$. Barbalha. CE. Brazil.

\begin{tabular}{|c|c|c|c|c|}
\hline Subperíodos & $\mathrm{I}\left(\mathrm{mm} \mathrm{d}^{-1}\right)$ & $\Delta \mathrm{h}\left(\mathrm{mm} \mathrm{d}^{-1}\right)$ & $\mathrm{D} / \mathrm{C}\left(\mathrm{mm} \mathrm{d}^{-1}\right)$ & $\operatorname{ETc}\left(\mathrm{mm} \mathrm{d}^{-1}\right)$ \\
\hline- & 39.5 & - & - & - \\
\hline 1 & 19.8 & -3.7 & 3.8 & 5.0 \\
\hline 2 & 15.8 & 3.7 & 4.5 & 6.0 \\
\hline 3 & 31.6 & 0.5 & 8.2 & 5.0 \\
\hline 4 & 44.7 & -6.1 & 11.8 & 7.2 \\
\hline 5 & 35.6 & 14.2 & 10.7 & 7.6 \\
\hline 6 & 94.8 & 14.6 & 6.4 & 14.5 \\
\hline 7 & 34.2 & -11.7 & -3.4 & 2.7 \\
\hline 8 & 52.7 & 9.2 & -3.8 & 8.3 \\
\hline 9 & 54.0 & 15.0 & -4.2 & 9.3 \\
\hline 10 & 30.3 & -6.1 & -4.6 & 3.9 \\
\hline 11 & 28.9 & -14.6 & -3.7 & 1.3 \\
\hline 12 & 54.0 & 20.3 & -2.8 & 10.2 \\
\hline 13 & 31.6 & -10.9 & -2.4 & 2.0 \\
\hline
\end{tabular}

$\mathrm{I}=$ irrigation; $\Delta \mathrm{h}=$ soil water storage variation; $\mathrm{D} / \mathrm{C}=$ deep drainage (negative values) or capillary rise (positive values) flows; ETc = crop evapotranspiration.

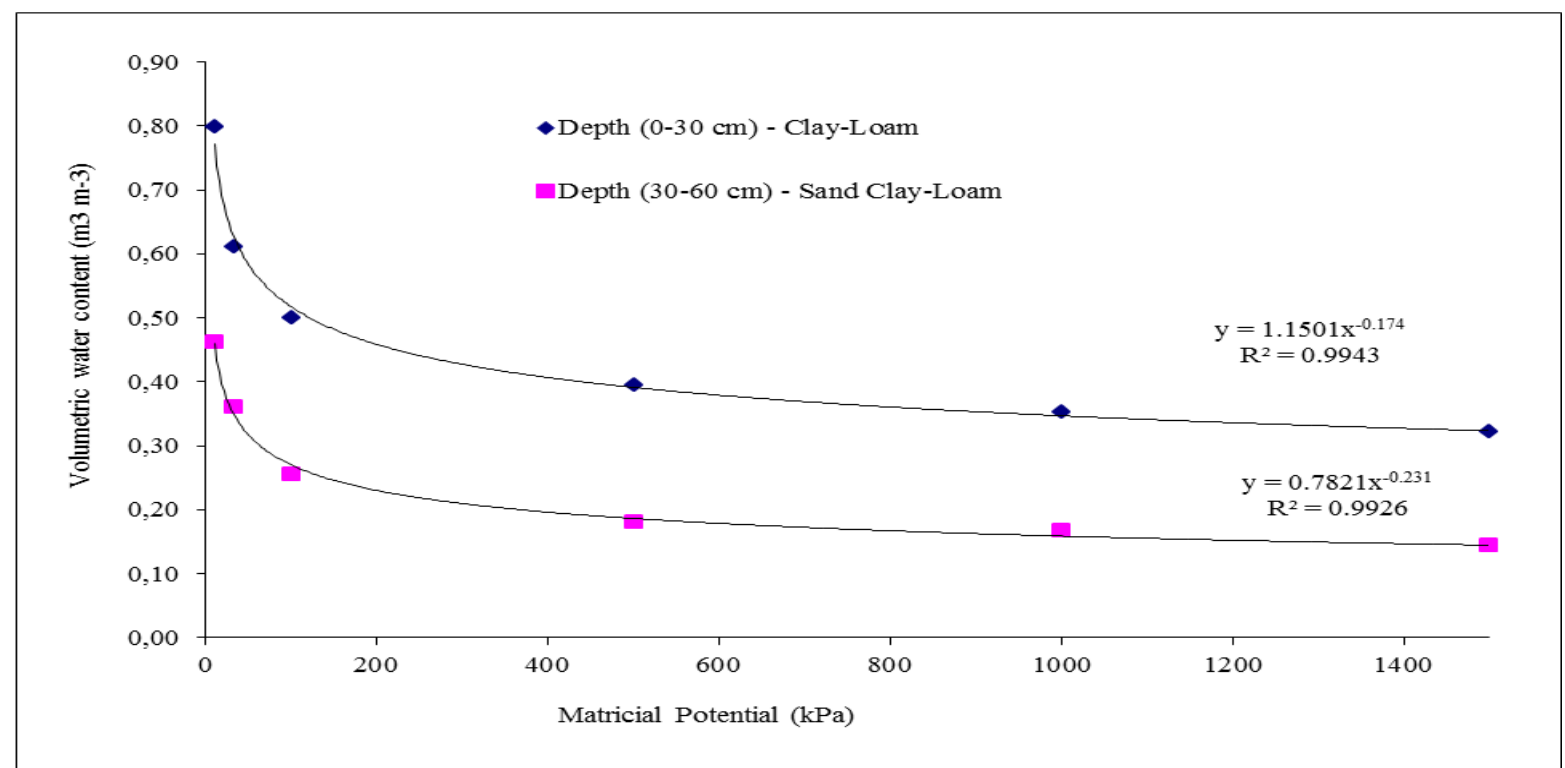

Figure 3. Soil water retention curves at 0-30 and 30-60 cm depths. Barbalha. CE. Brazil. 2012. 


\section{J. R. Pereira et al.}

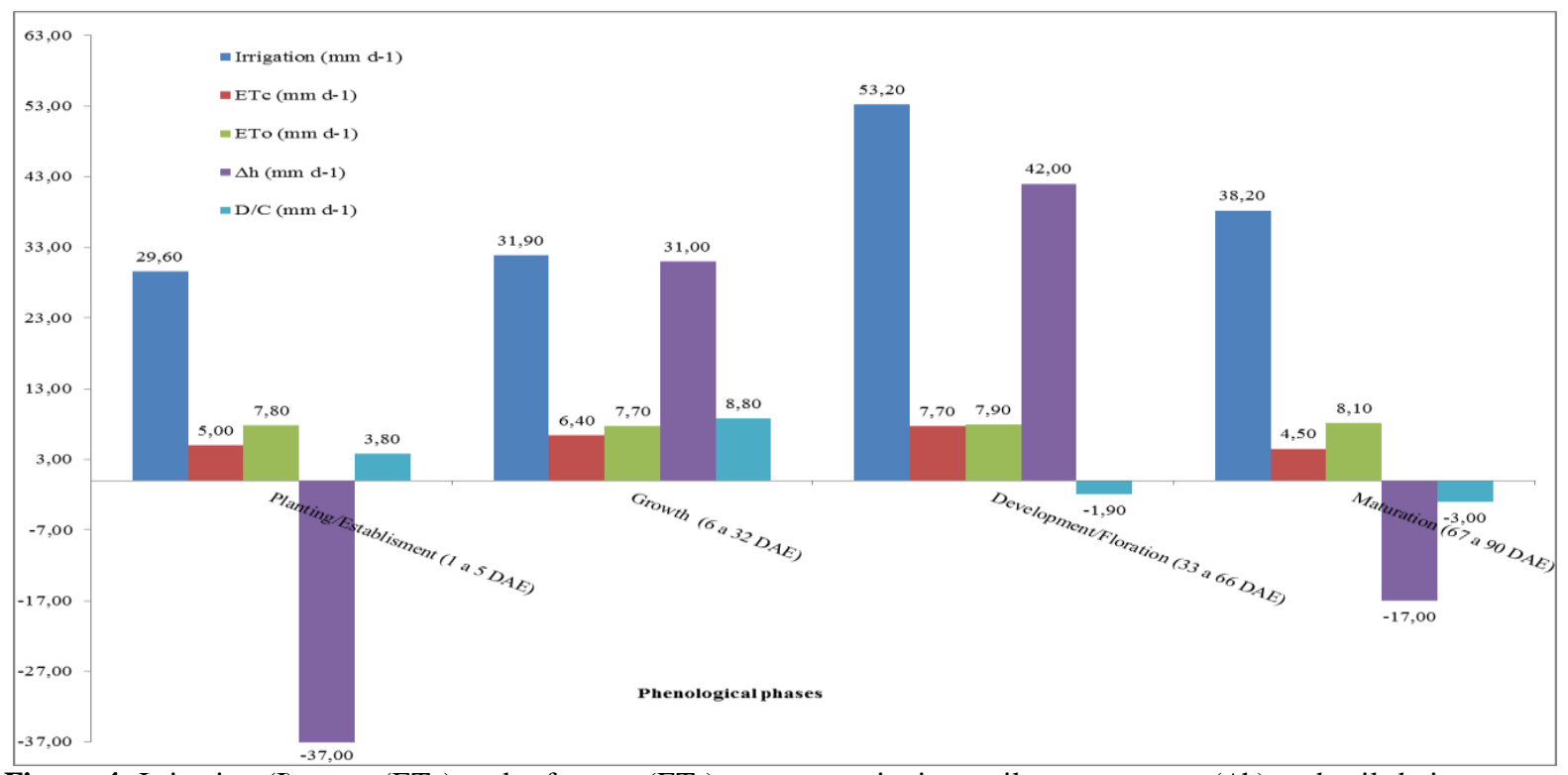

Figure 4. Irrigation (I). crop $(\mathrm{ETc})$ and reference $\left(\mathrm{ET}_{0}\right)$ evapotranspiration. soil water storage $(\Delta \mathrm{h})$ and soil drainage rates (D/C) daily averages for the different sesame BRS 196 CNPA G4 phenological phases. Barbalha. CE. Brazil. 2012.

Table 4. Kc mean values for sesame BRS 196 CNPA G4 phenological phases in the Barbalha. CE. Brazil. conditions. 2012.

\begin{tabular}{lccc}
\hline Phenological phase & Period (DAE) & Duration (Days) & Kc \\
\hline I - Planting/Establishment & 1 to 5 & 5 & 0.63 \\
II - Growth & 6 to 32 & 27 & 0.83 \\
III - Development/Floration & 33 to 66 & 34 & 0.97 \\
IV - Maturation & 67 to 90 & 24 & 0.56 \\
\hline
\end{tabular}

